\title{
The Implementation of Character Education in Indonesia High School Curriculum Program
}

\author{
Sulastri Rini Rindrayani \\ Study Program of Economic Education, Sekolah Tinggi Keguruan dan Ilmu Pendidikan (STKIP) PGRI Tulungagung, Indonesia
}

Received October 8, 2019; Revised December 18, 2019; Accepted December 25, 2019

Copyright $\odot 2020$ by authors, all rights reserved. Authors agree that this article remains permanently open access under the terms of the Creative Commons Attribution License 4.0 International License

\begin{abstract}
This study is a qualitative study that aims to determine the implementation of character education in economics in high school majoring in social studies based on the 2013 curriculum. The location chosen as a place is a high school in Tulungagung Regency, Indonesia using the 2013 curriculum. The key informants of this study are the Economics teachers and students majoring in social science. Data were collected using in-depth interviews, observation, and documentation. Data analysis with stages: data collection, data reduction, data display, and conclusion drawing/verification. The results of data analysis prove that Syllabus, lesson plans, and material made by teachers have contained character education planning as a result of MGMP economic subject convention. The implementation of character education in high schools is carried out through intracurricular and extracurricular activities. Cultivation of character education in economics subjects reflects the 18 national character and values of Pancasila. Besides, the entrepreneurial attitude is also embedded. Evaluation of character planting has been carried out by economics teacher through written, oral, structured, and unstructured assignments. Constraints on the implementation of character education are found in students, especially in less bright students. We recommended that the results of this study provide benefits for the practitioner and educator to improve students' character in the high school curriculum program.
\end{abstract}

Keywords Character Education, Economic Subjects, Curriculum 2013

\section{Introduction}

Formal education, which is a place for students to learn from elementary to tertiary level, requires character education. Primary preventive-based schools require fundamental changes in the structure and learning process in schools to minimize the factors associated with students who are considered preventive [1], [2]. As a preventive alternative, education is expected to develop the quality of the nation's young generation in various aspects that can minimize and reduce the causes of various cultural problems and national character. Therefore, teachers have an important role in the learning process by instilling character education for students, so that they have a nation's character that can filter out various global influences and be able to develop the nation's character in daily life.

Concern from the government is evident in the importance of character education with the publication of the 2013 curriculum. This curriculum is a refinement of the 2006 curriculum KTSP curriculum, where character education is written explicitly on the Basic Competencies that teachers must apply in the learning process. Formal education also has the obligation to instill character education in students by issuing Government Regulation No. 87 of 2017 concerning Strengthening of Character Education (PPK). The regulation emphasized that the implementation of PPK is carried out on 1) Educational Unit for Formal Education; 2) Educational Unit for Non-formal Education pathway, and 3). Educational Unit Informal Education pathway. Whereas in the formal pathway, KDP can be carried out on intracurricular, co-curricular; and extracurricular [3].

Presidential Regulation No. 87 of 2017 concerning Strengthening of Character Education (PPK) article: 7 Implementation of PPK in intracuricular activities, as referred to in Article 6 paragraph (1) verse a, is a reinforcement of character values through activities to strengthen learning materials and learning methods in accordance with curriculum content based on legislation [4]. This explanation can be interpreted that character education must be given to students through subject matter and method of study following the curriculum content of the subjects. 
Character education in the study of economics is expected to solve the economic problems encountered in meeting the needs of individuals or groups according to their physical capacity. Thus, students are not expected to bring problems to other people, the community, and the environment. The learning of economics based on character education can make students think broadly in all subjects so that they can increase social, religious, and cultural values automatically [5].

Economics subjects at the high school level based on the Minister of Education and Culture Regulation of the Republic of Indonesia Number 69 of 2013 concerning the Basic Framework and Curriculum Structure of Senior High Schools / Madrasah Aliyah has a character content on Basic Competence (KD) 1) in class X: Being honest, being disciplined, responsible, caring, creative, independent, critical, and analytical in overcoming economic problems, 2) in class XI: Being honest, disciplined, responsible, caring, creative, and independent in efforts to overcome development problems in Indonesia, 3) in class XII: Being honest, disciplined, responsible, caring, polite, responsive, and proactive in conducting trade activities and international economic cooperation as well as in conducting the accounting stages of service and trade companies [6].

The explanation shows that character education is a national movement that makes schools (formal education) as agents to build the character of students through learning and modeling. Therefore, the teacher has an important role in the success of instilling character education in students so that they become students who have achievement and character. Moreover, high school students are teenagers who have unstable personalities and seek an identity to form permanent characters. Education in adolescence becomes an important moment and determines a person's character as an adult. Based on these problems, the researcher wants to study more deeply about 1 ) how to plan character education in learning economic subjects in high school based on the 2013 curriculum, 2) how to implement character education in learning economic subjects in high schools based on the 2013 curriculum, and 3) how to evaluate Implementation character education in the study of economic subjects in high school based on the 2013 curriculum.

\subsection{The Concept of Character Education}

Character as an inner tendency can be relied upon to respond to situations in a morally good way. He added that the character contained has three interrelated parts, namely moral knowledge, moral feelings, and moral behavior [7]. Character education is not only to teach what is right and what is wrong in children but also instills good that is understood, felt, and wants to be done well by students. Character education is a mission similar to moral education or moral education [8]. Character traits should include but are not limited to, courage, good judgment, integrity, civility, kindness, perseverance, responsibility, tolerance, self-discipline, respect for school personnel, responsibility for school safety, service to others and good citizenship [9].

Therefore, education is a more important factor, not only to equip the new generation with skills that are essential for earning livelihoods but also to create among them an awareness of social and environmental realities and to instill in them a scientific temperament, independence of mind and soul. These things are very important for students who will be responsible citizens [10]. Thus, character education is a process of cultural inheritance and a national character to students to behave in a variety of virtues that are believed and used as a basis for perspective, thinking, behaving, and acting to improve the quality of community and nation living in the future.

\subsection{Character Value}

Based on the Development of Culture and Nation Character in 2010, there are 18 national characters, which are religious, honest, tolerance, discipline, hard work, creative, independent, democratic, curiosity, national spirit, love of the motherland, respect for achievement, friendship / communicative, peace-loving, fond of reading, caring about the environment, caring socially, and responsible [11].

The six characters which are pillars in character education are trust, justice, caring, respecting, good citizenship, and responsibility [7]. IHF developed the "Character-based Holistic Education" model. The curriculum used is the "Character-based Integrated Curriculum." There are nine pillars of character in the curriculum, namely: (1) God's love and God's creation; (2) independence and responsibility; (3) honesty / trustworthy; (4) respect and courtesy; (5) generous, care for help and mutual assistance/cooperation; (6) confident and hardworking; (7) leadership and justice; (8) kind and humble, and; (9) tolerance, peace and unity [12]. The main character values that are at the core of the application of character among students in school are honesty (from the heart), intelligence (from if thought), toughness (from sports), and caring (from taste and intention) [13].

Character values based on Government Regulation No 87 of 2018 on Strengthening Character Education confirms the Strengthening of Character Education (PPK) implemented by applying Pancasila values in character education primarily covering religious values, honesty, tolerance, discipline, hard-working, creative, independent, democratic, curiosity, national spirit, love of the motherland, respect for achievement, communicative, love for peace, love to read, care about the environment, care about social, and responsible [3].

Based on the curriculum structure of high school economics classes, X-XII, character education planted by students is honest, disciplined, responsible, polite, 
responsive and proactive, caring, creative, independent, and critical. Various opinions about the character values embedded in students aim to equip the cultural values and national character of students. The implementation of character education at the school level from each level and school is not the same. The application of character can be adjusted to the condition of the school such as supporting facilities and infrastructure, school culture, and the condition of students. However, the characteristics chosen to be applied in schools need to be determined by teachers and principals, which are planned to start from the vision, mission, and curriculum of the school unit level.

The purpose of Cultural Education and Nation Character was 1) developing the potential of the conscience / affective of students as human beings and citizens who have cultural values and national character; 2) develop the habits and behavior of students who are praiseworthy and in line with universal values and national cultural traditions that are religious; 3 ) instilling the spirit of leadership and responsibility of students as the next generation of the nation; 4) develop students' abilities to become independent, creative, national-minded human beings; and 5) developing the school life environment as a learning environment that is safe, honest, full of creativity and friendship, and with a high and strong sense of nationality (dignity) [11].

\subsection{The Learning Process in the 2013 Curriculum}

The learning process in the 2013 curriculum includes the development of the domains of attitude, knowledge, and skills that are elaborated for each education unit. The three competency domains have different trajectories (psychological processes). Attitudes are obtained through the activities of "accepting, executing, appreciating, experiencing, and practicing." Knowledge is gained through the activities of "remembering, understanding, applying, analyzing, evaluating, creating." Skills are obtained through the activities of "observing, asking, trying, reasoning, presenting, and creating." The characteristics of competence along with differences in acquisition pathways also influence the standard characteristics of the process. [4]

The explanation can be interpreted that the learning process can develop the realm of attitudes, knowledge, and skills together and integrated according to the competencies to be achieved. The learning process can provide opportunities for students to carry out activities in the realm of attitudes, knowledge, and skills.

The learning method based on the 2013 curriculum uses a scientific approach, thematically integrated between subjects, and thematic in one lesson. Meanwhile, the learning method uses the active student learning method in the learning process. The learning methods include (discovery/inquiry learning), project-based, and problem-based. All three methods use a scientific approach in their implementation.

Some recommendations of learning methods in implementing character education in schools are: 1) Incorporating the concept of character in each learning manner, a) Instilling the value of goodness in children (knowing the good). Instilling self-concept in children each will enter the subject matter; b) Making a way that makes children have a reason or desire to do good. c) Give some examples to children about the character being built; d) Develop an attitude of loving good deeds to children; e) Apply character in the learning process. 2) Make slogans that can foster good habits in all student behavior. 3) Continuous monitoring, this is a manifestation of the implementation of character building. 4) The parental assessment has a vital role in building the character of children because parents have more time for children than the school [14].

Based on this explanation, character education development can be done through curriculum content, learning and assessment processes, relationship quality, handling or managing subjects, managing schools, implementing activities, empowering infrastructure, financing, and the work ethic of all people and the school environment. Besides, the teacher has a big role in the success of character planting; therefore, teachers should provide role models for good character.

Character education is not a slogan or course but a school mission that is embedded in school daily life [15]. In other words, an educational policy must lead to the realization of moral education in the school system. Together with parents, teachers and school administrators as stakeholders must join this curriculum to encourage students to realize good values in student life.

\subsection{The Evaluation of Character Education in the Learning Process}

Process assessment based on Process Standard No. 22 of 2016 is explained as follows. Assessment of the learning process uses an authentic assessment approach that evaluates students' readiness, process, and learning outcomes as a whole [4]. The integrated assessment of the three components will illustrate the capacity, style, and learning outcomes of students who can produce instructional effects (instructional effects) on aspects of knowledge and the impact of accompaniment (nurturant effect) on aspects of attitude.

Authentic assessment results are used by teachers to plan remedial learning programs, enrichments, or counseling services. Also, authentic assessment results take part as material in improving the learning process per Education Assessment Standards. Evaluation of the learning process is carried out during the learning process by using tools: observation sheets, peer questionnaires, recordings, anecdotal notes, and reflections. Evaluation of learning outcomes is carried out during the learning process and at 
the end of the lesson, a unit using methods and tools: oral / deed tests, and written tests. The final evaluation results are obtained from a combination of process evaluation and evaluation of learning outcomes ".

\section{Methods}

This type of research is included in the category of qualitative research because it produces descriptive data in the form of written / verbal words from people or observable behavior. As an approach, researchers use phenomenology to be able to explain or uncover the meaning of concepts or experience phenomena that are based on an awareness that occurs in some individuals, namely teachers and students in Tulungagung District High School regarding the implementation of character education in learning economics.

The stages of field research consist of the pre-field stage, the stage of fieldwork, and data analysis [16]. The research subjects or key informants in this study were economics teachers and students majoring in social sciences in public high schools in Tulungagung Regency who used the 2013 Curriculum.

Following the characteristics of qualitative research that is natural, researchers determine the subject as a source of informants with purposive and snowball sampling. Purposive sampling is a data source sampling technique with certain considerations [17]. Snowball sampling is a data source sampling technique, which initially is small in number, gradually becomes large. This step is done because of the small amount of data sources that have not been able to provide complete data, so researchers must find other people as a source of data to obtain the data needed.

The location of the study was conducted at the State Senior High School in Tulungagung Regency using the 2013 curriculum. This type of research is included in the category of qualitative research because it produces descriptive data in the form of written / verbal words from people or observable behavior. As an approach, researchers use phenomenology to be able to explain or uncover the meaning of concepts or experience phenomena that are based on an awareness that occurs in some individuals, namely teachers and students in Tulungagung District High School regarding the implementation of character education in learning economics.

\subsection{Source and Type of Data}

The main data sources in this study were the words and actions of the subjects studied, namely high school economics teachers and students majoring in social studies. Meanwhile, additional data sources are in the form of documents that can support the data needed. The type of data in this study is in the form of words, actions, written data sources, and documents that can help data collection on the implementation of character education in learning economic subjects in high schools based on the 2013 Curriculum.

\subsection{Instrument and Data Collecting Technique}

In this qualitative study, the instrument or research tool is the researcher himself or the researcher as a human instrument. The researcher in this study functions to determine the focus of research, select informants as sources of data, collect data, assess data quality, analyze data, interpret data, and make conclusions on its findings [17]. Data collection methods in this study use: 1) In-depth interview method is used to collect data on the implementation of character education in learning economic subjects in high schools based on the 2013 curriculum. The informants in this study are teachers of economics and students majoring in Social Sciences in Tulunggaung Regency Public High School, 2) Participatory observation method is used to collect data on the implementation of character education learning. 3) Documentation is used to collect data planning for character education learning by looking at the document; curriculum, syllabus, lesson plans, textbooks, and evaluation devices.

\subsection{Data Analysis}

Analysis of the study was carried out by the interactive technique cited. Qualitative data are analyzed interactively and lasts continuously to completion so that the data is saturated [17]. The data analysis stages of this model are data collection, data reduction, data display, and conclusion drawing/verification. Reflect the interrelationships between stages. Meanwhile, to obtain a high degree of validity, it is done with triangulation and rechecks techniques. In this study, qualitative data were coded based on the planning, implementation and evaluation categories of character education programs [18].

\section{Results and Discussion}

\subsection{Result}

3.1.1. Character Education Planning in Learning Economic Subjects

"The lesson plan (RPP) was made jointly by economics teachers through a workshop in Malang held by the province. The preparation of the RPP was followed up at the district level conducted by MGMP in economics subjects"

"Syllabus, lesson plans, materials are compiled together with economics teachers in MGMP activities, so that 
lesson plans in economics at high school level in Tulungagung Regency are the same".

Meanwhile, according to (S) explain that

"Economic lesson plans in high school are compiled by economics teachers through the lesson plan compilation workshop based on the 2013 curriculum" While the syllabus structure, lesson plans, and material are discussed in MGMP for economics. "

Data collected using the application of learning tools in SMA Tulungagung Regency are in the form of 1) curriculum of economic subjects for SMA / MA, 2) Syllabus and lesson plan for economic subjects in high schools compiled based on the 2013 curriculum. 3) The availability of economic subjects textbooks by the 2013 curriculum, 4) List of student attendance and teacher journals on economic subjects.

Based on the results of interviews, documentation, and observations that show economics teachers in Tulungagung Regency high schools have made learning such as Syllabus, lesson plans, and materials used for economic learning based on the 2013 curriculum. The making of the Syllabus and lesson plan is done together through MGMP economic subjects. The syllabus and lesson plans resulting from the MGMP are used as the basis for implementing economic learning.

The results of interviews with economics teachers in Boyolangu (R) and Kedungwaru (S) high schools are as follows. How to make lesson plans with character education translation? '. (R) and (S) explained as follows.

"Character education planning contained in the RPP under the characters contained in economic subjects ... it is in KI religious attitude and K2 social attitude "so the teacher in the making RPP that includes character education while limited to the characters in the curriculum of economics subjects."

These findings indicate that character education in economic subjects has been written in the lesson plan. The characters planted by students are honest, disciplined, responsible, polite, responsive, and proactive, caring, creative, independent, and critical. The characters embedded in the learning process are still limited to the characters contained in the curriculum of economic subjects.

\subsubsection{Implementation of Character Education in Learning Economic Subjects}

The results of interviews with economics teachers at Boyolangu (R) and Kedungwaru (S) high schools below explain the implementation of character education in economic subjects in the learning process. What method do you use in explaining economics material?

The teacher (R) explained

"The method used is adapted to the learning objectives and subject matter if the count is like accounting with the direct learning method ... if students are bored I invite students to study outside the classroom ... they will not be bored again"

While the teacher (S) explained

"I used the problem-based discussion method ... how cool when explaining the workforce ... the kids were very happy because the children imagined the work that would come after graduation ... "I also use discussion methods with games; students will feel motivated ... even they want to answer first"

The results of interviews with an economics teacher at Tulungagung Regency High School showed that the applied method follows the learning objectives and material. They use active student methods according to the provisions of the 2013 Curriculum. Learning methods used include the discussion method with games, problem-based methods, and direct learning methods with performance.

How do you embed character education in your learning process? The teacher (R) explains

"In Boyolangu High School, character education is carried out every day ... every time I enter the classroom by 1) singing the Indonesia Raya song, 2) Praying, 3) every Wednesday and Saturday there is a literacy activity where students are given 30 minutes to read in the class library even this activity is contested. 4) every Friday led by religious teachers read Yasin or short surahs.

"Are there planted characters other than Mom's class? "Planting of character is not only intracuricular but also through extra-curricular activities. For example, we have a school cooperative managed by students majoring in social studies. They become administrators and annually hold annual member meetings (RATS) which are attended by the Head of the Tulungagung District Education Office. ... they even have two employees, one cleaning employee and one other employee. Students are required to become members of the cooperative where the required savings of only Rp. Two thousand are paid annually. ... if you pass the cooperative money, both basic savings and must be returned."

"In addition to cooperative extracurriculars, we have an extracurricular scout in which there is entrepreneurship. Students sell cakes at recess to their friends or in the teacher's lounge. Cakes that are sold are taken from the producers and then sold ... so train students to be entrepreneurs."

"Every year, high schools hold exhibitions or stands that sell students' work ... social activities during the fasting month are done with compensation to orphans ... we also give to elementary school children when the bike is healthy."

"Compared to the rest of the science majors, social studies students have a higher social status ... meaning they are helping and high tolerance ... once a friend did not have money to pay for a standard... then the children 
paid dues so that his or her friend who couldn't afford earlier could join."

The results of direct interviews with high school economics teachers in the Tulungagung Regency show that: 1) Embedding character attitudes are carried out in the learning process for example: singing the great Indonesian song and praying before starting the lesson. 2) Literacy activities every Saturday and Wednesday to motivate students to read; 3) Every Friday reading Yasin surahs or short surahs by all students led by religious teachers; 4) Character implementation is carried out on extra-curricular activities, namely school cooperatives and scouts in which entrepreneurship is trained; and 5) Social activities are carried out every year through the assistance of orphans in the fasting month, provide compensation to children in the nearest elementary school, and care and help to friends who do not have.

The question about the media used in economic learning for teachers (R) is "what media are used in the learning process?"

"- through Whatsapp... with such students have material to be discussed. Also, students have preparations before delivering the material."

The results of the interview can be explained that the learning media of economics subjects use PowerPoint, videos, and students to look for the material themselves. For the material to be studied by students, the teacher provides material through the WA group belong to the classes.

\subsubsection{The Evaluation of Character Education Implementation Learning Economic Subjects}

The teacher gets a question of how to evaluate the implementation of character education in and (S) What is the process of evaluating the learning of economics?

Teacher explanation (R) "evaluation of learning using written tests, oral tests, and assignments. Because the 2013 curriculum is used, then the evaluation uses the basis of Kurikulu 2013... Every KD is always evaluated both with tests and assignments .... so it can't be basic to give grades but an assessment of each basic competence (KD)

Teacher's explanation (S) is "I always assess every activity in the learning process ... both at the time of discussion, the time of presentation or when the teacher explains. An active child will receive an award in the form of points that can add value. So before conducting the evaluation, I made an assessment rubric that was appropriate to the activity being assessed. If there is a discussion on the assessment of the questions worked on and rubric assessment for discussion activities ... crazy ... the assessments, ma'am.

The explanation shows that the teacher has conducted an authentic assessment, as recommended in the 2013 curriculum. Every KD subject is always evaluated both using written tests, oral tests and assignments. The assessment guidelines used in the form of an assessment rubric following the tasks assigned, namely the assignment rubric, oral assessment, and written assessment.

\subsection{Discussion}

\subsubsection{Character Education Planning in Learning Economics in High School Social Sciences Department}

The findings in the field show that character education planning has been planned; the character's attitude has been written on the syllabus and lesson plans. The attitude of the character is embedded following the provisions contained in the structure of the curriculum of economic subjects for SMA / MA. The attitude of the characters contained in the RPP in accordance with the Regulation of the Minister of Education Education and Culture of the Republic of Indonesia Number 69 of 2013 concerning the Basic Framework and Curriculum Structure of High School / Madrasah Aliyah has a character load on Basic Competence (KD) 1) Class X: Being honest, disciplined , responsibility, caring, creative, independent, critical and analytical in overcoming economic problems, 2) Class XI Being honest, disciplined, responsible, caring, creative, and independent in efforts to overcome development problems in Indonesia, 3) Class XII Being honest, discipline, responsibility, caring, polite, responsive and proactive in conducting trade activities and international economic cooperation as well as in carrying out the accounting stages of service companies and trading companies [6].

\subsubsection{The Implementation of Character Education in Learning Economic Science Subjects}

The implementation of character education is done through intracuricular and extracurricular activities. This explains that character education must be given to students through subject matter and method of learning under the contents in the curriculum of the subject [4].

Implementation of intra-curricular character education is carried out in the process of learning economic subjects in the form of, singing the Indonesia Raya song together which is led by one of the students and continued with prayer, led by the class leader. This activity embeds the attitude of religious character and patriotism. The application of this attitude is a reflection of the values of the nation's character in accordance [11] which describes the development of culture and national character.

Character education is poorly defined within recent government initiatives and policy documents and it appears as though that ambiguity is reflected at the level of teacher education in universities and schools [19]. The embedding of the character's attitudes in the learning process is reflected in the learning methods used by teachers referring to learning objectives and learning material. The attitude of the character that is instilled in the learning process is not 
directly is honest, disciplined, responsible, caring, creative, independent, critical, analytical, polite, responsive and proactive. Learning methods used in explaining economic material include problem-based discussion methods, direct learning methods, project-based methods.

The use of problem-based discussion methods that have the characteristic of giving contextual problems makes children think critically in solving problems with discussion and problem solving using a variety of learning resources, and are required to achieve the products of problem-solving. This problem method will be honest, disciplined, responsible, caring, creative, independent, critical, analytical, polite, democratic, responsive, and proactive.

Besides, the learning methods used by economics teachers are also following the provisions of the 2013 curriculum which emphasizes that learning methods that make students active in the learning process are problem-based, project-based, discovery and thematic methods. To encourage the ability of students to produce contextual work, both individually and in groups, it is strongly recommended to use a learning approach that produces work based on problem-solving (project-based learning) [4]

The economics teacher in the learning process has been able to develop the realm of attitudes, knowledge, and skills together and integrated according to the competencies to be achieved. The learning process is designed to provide opportunities for students to carry out activities in the realm of attitude, knowledge, and skills.

In addition to the learning process, Boyolangu High School also requires literacy activities every Wednesday and Saturday for 30 minutes. This literacy activity is obliging students to read reading books in the library according to their interests; even this activity has been contested. The purpose of this activity is to cultivate students who love to read. Meanwhile, to embody religious attitudes carried out by holding activities reading surah Yasin or other short surahs every Friday led by teachers who teach Islamic subjects.

\subsubsection{The Implementation of Character Education in Extracurricular Activities}

The inculcation of the character of social science students' attitudes on economics is carried out through the implementation of daily life through extracurricular activities namely cooperatives, scouts, and social activities. In cooperative activities, students are trained to carry out cooperative management to play a role in managing cooperatives. The cooperative business is in the form of a commercial business, where students buy and then sell. Most of the products are sold from students, students' parents. Every student is required to become a member of a cooperative. Savings required per month 2000 rupiah is paid at the beginning of each year together with SPP payments. Principal and mandatory savings will be returned when students graduate. This cooperative management will instill honesty, responsibility, independence, responsibility, discipline, hard work, responsiveness, and dare to take risks. Besides this cooperative management will provide knowledge, skills, and attitudes to students in cooperative management that can support understanding economic subjects, and can be used as a provision to plunge in the community.

In extracurricular scout activities, students are trained in entrepreneurship. Students are trained to sell cakes to their themes during breaks or in the teacher's lounge. This activity will instill honesty, responsibility, independence, discipline, hard work, responsiveness, and dare to take risks. This activity can provide knowledge, skills, and characteristics of an entrepreneur who can be used as an entrepreneurial provision.

Social activities are also carried out every year during the fasting month by providing benefits to orphans around Tulungagung Regency. Social care activities are also carried out when his or her friend cannot participate in activities. For example, when one person cannot pay the study tour fee, then the other friends in one class will make contributions so that the student can participate. This activity instills an attitude of social care, religious, tolerance, and friendship.

Thus, Tulungagung Public High School has implemented the 2013 curriculum specifically the Social Sciences department that has instilled character education for 18 national characters namely religious, honest, tolerance, discipline, hard work, creative, independent, democratic, curiosity, national spirit, love of the motherland, respect for achievement friendly/communicative, peace-loving, fond of reading, caring for the environment, caring socially and responsibly [10] while applying the character found in the values of Pancasila [13]. In addition to these characters, some characters are instilled in students to strengthen economic subjects, namely the cultivation of the character of entrepreneurial spirit, among others, dare to take risks, thorough and confident.

\subsubsection{The Evaluation of the Implementation of Character Education in Learning Science Economics}

Character education requires young people can judge what is true, very concerned about what is true, and then doing what is right, even in the face of external pressures and temptations from within [20], because they must get welfare with respect to their self-concept. Nature educators in building character are must strive to help students perform charitable acts, polite, and self-discipline repeatedly.

Evaluation of Character Education in learning economic subjects is carried out every basic competency by authentic assessment Evaluation is carried out using written tests, oral tests and giving structured or unstructured tasks. The attitude assessor is done with the rubric of assessment at 
the time of discussion and task completion. Whereas, the assessment of extracurricular activities does not yet have a special assessment sheet to measure attitudes. Assessors are measured by the attendance and involvement of students in this activity.

\section{Conclusions}

Based on the results of the field research, it can be concluded that Boyolangu Public High School and Kedugwaru Public High School, which are the 2013 Curriculum pilot school in Tulungagung Regency in the implementation of Character Education in economic subjects especially in the Social Sciences major are carried out as follows:

1. The learning plan includes a Syllabus, lesson plan, and material made by economics teacher through MGMP. The attitude of the characters that will be instilled in students in the learning process is already contained in the syllabus and lesson plans. The attitude of the characters contained in the syllabus, lesson plans, and subject matter is an attitude of religious and social character contained in the basic competencies of economic subjects based on the 2013 curriculum. Planting characters in the learning process is carried out starting from the preliminary activities, the implementation of learning and the closing activities. Other intracuricular activities to inculcate character are literacy and reading Yasin or other short surahs.

2. The implementation of character education is conducted through intra-curricular and extra-curricular activities that support the competence of economic subjects. In intracuricular planting of character education through the learning process that is reflected in the learning methods used. Whereas in extracurricular character education planting through cooperative management activities, scouts, social care. Character education that has been carried out is 18 national characters and at the same time the application of Pancasila values. In addition to the 18 national characters, the cultivation of characters that can support knowledge, skills, and attitudes of economic learning is applied, namely the character of the entrepreneurial spirit (cooperative management and entrepreneurship) in the form of planting a risk-taking, thorough and confident attitude.

3. The Evaluation of the implementation of character education has been carried out by economics teachers through written tests, oral tests, structured assignments, and unstructured assignments. The evaluation of investment characterization is evaluated during the process and results. The teacher has also prepared a guide to attitude assessment and results from assessment guidelines. While the research guidelines for instilling attitude toward character do not yet exist, while the assessment is based on the presence and involvement in activities.

4. The obstacle of teachers in implementing education in learning economic subjects is found in students, especially in students who are not smart. Less clever students cannot follow the lessons like their friends who are quick to understand the material. Therefore, in addition to the consistent implementation of intra-curricular and extra-curricular activities, meaningful learning needs to be carried out that emphasizes the concept of decaying all students and special attention to students not or less intelligent, for example through scaffolding treatment.

\subsection{Suggestion}

Based on the findings, the researcher suggests that character inculcation through extracurricular activities needs to be improved so that it can strengthen character planting in subjects. The assessment of character attitudes on extracurricular activities needs to be done by making guidelines for character attitude assessment.

Teachers have a big role in the success of character education. Therefore teachers must be able to give examples of the application of character in daily life at school and in the community if the teacher has the character so easily able to overcome the obstacles in the application of character, especially in the learning process.

\section{Acknowledgements}

We are very grateful to experts for their appropriate and constructive suggestions to improve this template.

\section{REFERENCES}

[1] J. D. Hawkins and J. S. Wall, Exploring the delinquency prevention potential. Washington D.C: U.S Department of Justice, 1980.

[2] M. F. Amir, I. A. Mufarikhah, A. Wahyuni, Nasrun, and H. E. Rudyanto, "Developing 'Fort Defending' Game as a Learning Design for Mathematical Literacy Integrated to Primary School Curriculum in Indonesia," Elem. Educ. Online, vol. 18, no. 3, pp. 1081-1092, 2019.

[3] Y. H. Laoly, Peraturan Presiden Republik Indonesia Nomor 87 Tahun 2017 Tentang Penguatan Pendidikan Karakter. 2017, pp. 1-14.

[4] A. Baswedan, "Peraturan Menteri Pendidikan dan Kebudayaan Nomor 22 Tahun 2016 Tentang Standar Proses Pendidikan Dasar dan Menengah,” 2016.

[5] R. Hadi, "The Integration of Character Values in the Teaching of Economics : A Case of Selected High Schools 
in Banjarmasin," Int. Educ. Stud., vol. 8, no. 7, pp. 11-20, 2015.

[6] M. Nuh, "Peraturan Mentri Pendidikan dan Kebudayaan Republik Indonesia No 69 Tahun 2013 Tentang Kerangka Dasar Struktur Kurikulum Sekolah Menengah Atas /Madrasah Aliyah," Peratur. Pemerintah Republik Indones. No 69 Tahun 2013, pp. 1-253, 2013.

[7] T. Lickona, Educating for Character: How Our School Can Teach Respect and Responsibility. New York, Toronto, London, Sydney, Aucland: Bantam Books, 1991.

[8] S. A. Kamaruddin, "Character Education and Students Social Behavior," J. Educ. Learn., vol. 6, no. 4, pp. 223-230, 2012.

[9] A. Pala, "The Need for Character Education," Int. J. Soc. Sci. Humanit. Stud., vol. 3, no. 2, pp. 23-32, 2011.

[10] P. L. Mehta and R. Poonga, Free and Compulsory Education, 1st ed. New Delhi: Deep and Deep publication, 1997.

[11] Said Hamid Hasan, Pengembangan Pendidikan Budaya dan Karakter Bangsa. 2010.

[12] E. Mulyatiningsih, "The Analysis of Character Education Models for Children, Adolescents and Adults," Ft Uny, pp. $1-18,2010$.

[13] Marzuki, "Intergating character education in the teaching and learning at school," J. Pendidik. Karakter, vol. 2, no. 1, pp. 33-44, 2012.

[14] I. K. Ahmadi and S. Amri, Mengembangkan pembelajaran IPS Terpadu. Jakarta: PT Prestasi Pustakaraya, 2011.

[15] A. Katilmiş, H. Ekși, and C. ÖztÜrk, "Efficiency of Social Studies Integrated Character Education Program," Educ. Sci. Theory Pract., vol. 11, no. 2, pp. 854-859, 2011.

[16] L. J. Moleong, Metodologi penelitian kualitatif. Bandung: PT. Remaja Rosda Karya, 2002.

[17] Sugiyono, Metode Penelitian Kuantitatif, kualitatif dan R \& D. Bandung: Alfabeta, 2013.

[18] S. MacAulay, B. M. Lagan, and K. Casson, "Planning, implementation and evaluation of antenatal weight management programmes: What are the key components? A mixed methods study," Midwifery, vol. 79, 2019.

[19] L. Revell and J. Arthur, "Character education in schools and the education of teachers," J. Moral Educ., vol. 36, no. 1, pp. 79-92, 2007.

[20] M. W. Berkowitz and J. H. Grych, "Early Character Development and Education," Early Educ. Dev., vol. 11, no. 1, pp. 55-72, 2000. 